Syntax Literate: Jurnal Ilmiah Indonesia p-ISSN: 2541-0849

e-ISSN: 2548-1398

Vol. 6, No. 5, Mei 2021

\title{
JALAN TERJAL ONLINE TRAVEL PLATFORM HADAPI PANDEMI
}

\section{Komang Gita Krishna Murti dan Gede Sri Darma}

Universitas Pendidikan Nasional, Denpasar Bali, Indonesia

Email: krisnasiva12@gmail.com dan sridarma@undiknas.ac.id2

\section{Abstract}

This study aims to explore how the strategies that start-up companies are implementing to survive during a pandemic crisis. Previous research on Competitive Intelligence and Marketing 4.0 was used as a guide in the preparation of interview questions and data analysis. Data were collected through a semi-structured in-depth interview process involving 6 main sources, CEO and CMO of BestHostels Indonesia, 2 property owners who registered their property at BestHostels Indonesia, and also 2 consumers who had made reservations more than 2 times on the BestHostels Indonesia platform. The data were analyzed through a coding and theming process. This research indicates that 4 main factors that make bestostels Indonesia survive during a pandemic crisis, that is competitive intelligence, marketing 4.0, citizen 4.0, and also investor funding. This study offers a comprehensive model to understand the factors that influence the success of a startup is facing a crisis. This model can be used as a reference for subsequent research to obtain empirical evidence that can be generalized regarding the factors that influence the success of startups in facing crises. Also, this research can also be used as a valuable reference for individuals who want to start their own start-up company and the right strategy to use.

Keywords: digital platform; competitive intelligence; marketing 4.0, investor funding, citizen 4.0; covid 19

\section{Abstrak}

Penelitian ini bertujuan untuk mengeksplorasi bagaimana strategi yang perusahaan rintisan lakukan untuk dapat bertahan di saat krisis pandemi sedang terjadi. Penelitian Competitive intelligence dan marketing 4.0 terdahulu digunakan sebagai panduan dalam penyusunan pertanyaan wawancara dan juga analisis data. Data dikumpulkan melalui proses wawancara secara mendalam semi-terstruktur yang melibatkan 6 narasumber utama yaitu CEO, CMO dari besthostels Indonesia, 2 pemilik property yang mendaftarkan propertynya di besthostels indonesia dan juga 2 konsumen yang sudah lebih dari 2 kali melakukan reservasi di platform besthostels Indonesia. Data kemudian dianalisis melalui proses coding dan themeing. Penelitian ini mengindikasikan terdapat 4 faktor utama yang membuat bestostels Indonesia dapat bertahan disaat terjadinya krisis pandemi, yaitu competitive intelligence, marketing 4.0, citizen 4,0 dan juga investor funding. Penelitian ini menawarkan sebuah model yang komprehensif untuk memahami 'faktor faktor' yang mempengaruhi keberhasilan sebuah perusahaan rintisan menghadapi krisis. Model ini dapat dijadikan sebagai acuan bagi penelitian berikutnya untuk mendapatkan bukti empiris yang dapat pada generalisasi terkait faktor faktor yang mempengaruhi keberhasilan perusahaan rintisan 
menghadapi krisis. Selain itu, penelitian ini juga dapat dijadikan refrensi berharga bagi individu yang ingin memulai perusahaan rintisan nya sendiri dan strategi yang tepat untuk digunakan.

Kata Kunci: platform digital; competitive intelligence; marketing 4.0; investor funding; citizen 4.0 , covid 19

\section{Pendahuluan}

Saat ini kita ketahui dunia sedang menghadapi krisis pademi yang memiliki dampak sangatlah luas. Sektor pariwisata dan juga bisnis yang ada di dunia mengalami dampak yang sangat besar dimulai dari banyak yang menutup usaha, merumahkan pegawai nya hingga menyatakan diri bangkrut karena pembatasan kegiatan masyarakat saat ini (Kim, 2020). Hal serupa lebih dirasakan di Bali yang menurut data dari Badan Pariwisata Dunia di tahun 2018, sekitar 12 juta warga Indonesia menggantungkan diri pada sektor pariwsata, dengan mayoritas diantara mereka tinggal di Bali. Hal ini dapat dilihat dari banyak nya toko, restaurant hingga hotel yang menghentikan kegiatan usaha di daerah yang dulu sangat ramai seperti kuta, nusadua dan canggu.

Indonesia sendiri sudah memasuki fase pandemi yang dinawamakan era new normal atau kenormalan baru dengan di normalisasi kegiatan operasional beberapa sektor bisnis sambil menerapkan protokol Kesehatan untuk menekan angka penyebaran virus (Andriani, S.Si, Apt, M.Sc, Ph.D, 2020). Walaupun sudah memasuki fase baru masih banyak usaha besar dan kecil yang terdampak seperti misalnya perusahaan rintisan atau startup yang baru berdiri tahun 2018 yang berasal dari Bali dengan market yang sangat spesifik yaitu Besthostels Indonesia. Platform sektor pariwisata ini menawarkan pilihan hostels yang ada di seluruh Indonesia dengan pilihan terlengkap dan juga terjangkau. Di mulai sejak bulan Desember 2018, Besthostels Indonesia berkomitmen untuk membantu para pengusaha hostel terutama di Bali, untuk menjadi wadah dunia perhostelan supaya hostel mulai dilirik oleh masyarakat Indonesia, terutama kaum milenial yang hobi berwisata untuk mencari pengalaman baru dan dengan budget yang terbatas.

Tren yang sedang terjadi belakangan di Indonesia adalah para wisatawan backpacker yang memilih untuk menghemat biaya untuk akomodasi menginap akan tetapi mengeluarkan biaya lebih untuk berwisata di rekreasi lain yang ada di destinasi tersebut. Para backpacker biasanya akan mencari penginapan termurah yang sesuai dengan kebutuhan nya untuk berisitirahat seperti guesthouse,homestay dan juga hostel (Turgut et al., 2016).

Trend ini juga didukung digital nomad yang didominasi oleh generasi milenials yang bisa bekerja dari mana saja yang penting tersedia koneksi internet. Hal ini dimungkinkan karena kemajuan teknologi informasi yang sedemikian pesat menjadi katalis untuk perkembangan digital platform dan juga remote working di seluruh dunia (Agung \& Darma, 2019). Dengan adanya teknologi yang memungkinkan hal tersebut untuk dilakukan dan trend nya terus bertumbuh, akhirnya berkembang sebuah startup yang khusus menawarkan hostel di Indonesia untuk mereka yang ingin merasakan pengalaman berwisata yang berbeda.

Di hostel mereka dapat berkenalan dengan teman baru yang berasal dari manca negara dan dari latar belakang yang berbeda, apalagi kaum milenials terkenal dengan generasi 
yang terbuka dan sangat senang untuk mengetahui hal baru (Godovykh \& Tasci, 2020). Maka dari itu menginap di hostel menjadi pilihan yang menguntungkan, selain harga lebih terjangkau mereka juga dapat mengenal orang baru dan bertukar pengetahuan. Setiap hostel juga menyediakan pelayanan seperti snack gratis, tempat terbuka dan meja panjang untuk berinteraksi dan juga bekerja dengan adanya koneksi internet. Tapi kebebasan dan keterbukaaan yang menjadi hal istimewa itu terhambat dengan kedatangan krisis pademi covid 19 yang dimulai pada awal tahun 2020 ini. Mereka yang suka berpergian dipaksa untuk diam dirumah untuk mengurangi penyebaran virus. Beberapa negara juga melakukan lockdown dan pembatasan berskala besar untuk dapat menanggulangi krisis pademi ini. Akibat nya banyak bisnis yang tidak siap menghadapi krisis memilih untuk gulung tikar, merumahkan karyawan nya hingga melakukan PHK secara besar besaran.

Dari sektor high technology yang diramalkan oleh banyak pihak akan memiliki pertumbuhan sangat besar dan mendisrupsi bisnis konvensional pun tidak terhindarkan dari krisis. Perusahaan decacorn seperti grab saja memberikan PHK kepada 360 pegawai nya. Dapat dilihat juga dari kesulitan AirBnB untuk memberikan refund kepada para pelanggan nya dan juga kesulitan memberikan bantuan kepada para pemilik property nya yang saat ini sedang kesulitan karena tidak ada tamu yang datang. Data yang dikeluarkan oleh iResearchChina.com menunjukan bahwa sektor pariwisata adalah salah satu sektor yang paling terdampak dengan adanya krisis pademi saat ini, selain juga dine-in restaurant.

Bukan hanya sektor pariwisata konvensional saja yang terdampak karena pandemi, bahkan startup Platform di sektor pariwisata seperti OYO menghentikan kerjasama nya dengan banyak hotel, villa dan akomodasi penginapan lain nya diseluruh dunia. Dan yang terbaru adalah berhenti nya operasional Airyroom di indonesia. Krisis pandemi ini juga sangat berdampak kepada ekonomi Bali yang sangat bergantung dengan sektor pariwisata, daerah yang dulu nya sangat ramai seperti kuta, nusadua dan canggu sekarang sangatlah sepi karena pembatasan di pintu masuk bali untuk wisatawan dari luar dan dalam negeri oleh pemerintah pusat dan provinsi. Hal tersebut berdampak pada banyak café, restaurant, hotel dan akomodasi wisata lain yang menutup operasional nya. Bisa dibayangkan bagaimana dampak dari krisis pademi saat ini kepada usaha hostel yang sangat memerlukan interaksi orang berkumpul dan tidur bersama di dalam satu ruangan. Selain itu hal ini juga mempengaruhi Besthostels indonesia sebagai startup online travel agent yang menaungi ratusan hostel diseluruh indonesia dan di pulau bali.

Sebelum terjadi nya krisis pandemi, di dunia bisnis terjadi fenomena perpindahan (shifting) secara massif dari bisnis yang menggunakan cara lama, dengan mereka yang menggunakan cara cara baru. Saat itu banyak perusahaan mengalami stagnansi karena tidak dapat menyesuaikan diri dengan selera pasar dan tren digitalisasi pada saat itu. Perusahaan seperti Bluebird dan Hilton yang begitu digdaya pada masa lalu pun terhambat pertumbuhan nya karena kedatangan perusahaan berbasis digital seperti GO-JEK dan Traveloka. Akan tetapi karena krisis pandemi tren digitalisasi malah ber akselerasi lebih cepat lagi (Geng et al., 2020).

Dalam era yang penuh dengan ketidak pastian ini, seperti yang sering disebut oleh Hermawan Kartajaya (2017) sebagai era VUCA (Volatility, Uncertainty, Complexity dan 
Ambiguity) perusahaan terkadang bingung untuk memulai strategi dari mana. Apakah mereka membuat sebuah inovasi yang baru atau menduplikasi produk dan jasa dari perusahaan sejenis yang disukai oleh mayoritas konsumen. Maka dari itu penggunaan competitive intelligence menjadi pilihan utama untuk para perusahaan memulai langkah awal dalam penyusunan strategi mereka (Dewi; Darma, 2019). Sistem ini memberikan pengetahuan yang koheren bagaimana posisi perusahaan dalam persaingan, bagaimana pesaing sukses dengan produk nya, bagaimana selera konsumen saat ini hingga bagaimana gejolak politik di sebuah negara dapat berdampak kepada proses bisnis mereka (Maritz \& du Toit, 2018). Maka dari itu pemanfaatan competitive intelligence yang tepat dapat membantu Online Travel Agent dan perusahaan rintisan yang mendirikan digital platform dalam memetakan jalan terjal dikala pandemi seperti saat ini untuk mencari peluang pertumbuhan dan dapat bertahan dikala startup besar lain nya jatuh.

Selain itu pemanfaatan media untuk melakukan promosi dan penawaran pun saat ini dipaksa untuk berubah. Karena masyarakat banyak menghabiskan waktu nya dirumah, penggunaan media billboard dan juga media cetak menjadi kurang efektif (Seyyedamiri \& Tajrobehkar, 2019). Maka dari itu marketing 4.0 adalah keniscayaan dikala pademi saat ini. Di dunia marketing saat ini, kehadiran dari teknologi informasi memberikan dampak yang signifikan. Berbagai kegiatan beralih lokasi dari dunia luar jaringan seperti billboard ke dunia maya (Dewi; Darma, 2019).

Didukung oleh jumlah pengguna internet di Indonesia yang mencapai 175juta pengguna atau sudah mencapai 64\% dari populasi keseluruhan Indonesia (WeAreSocial 2020), membuka peluang yang sangat besar untuk setiap perusahaan menjual dan memasarkan produk nya secara digital. Media sosial adalah salah satu media digital yang sangat luas digunakan dan mendukung perusahaan dalam menjalankan bisnisnya (Swari \& Darma, 2019).

Mehmet (Ali Köseoglu et al., 2016) dalam penelitian competitive intelligence practice in hotels menyimpulkan bahwa manajemen puncak hotel yang menerapkan CI dalam perancangan strategi nya memiliki tingkat kinerja yang lebih baik di bandingkan dengan manajemen puncak yang tidak menerapkan CI di perusahaan nya. Sebenar nya banyak manajemen puncak yang melakukan langkah langkah CI seperti menganalisa competitor, melihat lingkungan bisnis nya dan juga menyesuaikan harga sesuai pasar tapi tidak sadar telah melakukan CI dalam perusaaaan mereka. Tapi walaupun hampir semuanya memiliki pelatihan dalam strategi yang diperlukan untuk mengumpulkan informasi pesaing mereka, tetapi hanya sedikit yang menunjukkan hubungan yang jelas dengan perencanaan strategis dan perencanaan CI.

Selain itu penelitian Intrinsic motivation for knowledge sharing - competitive intelligence process in a telecom company yang dilakukan oleh (de Almeida et al., 2016) menemukan bahwa CI berpengaruh positif terhadap motivasi berbagi pengetahuan antara pegawai di perusahaan. Penelitian ini mengkonfirmasi 9 dari 11 hipotesis yang diajukan, yang menunjukkan elemen penting dari motivasi berbagi pengetahuan dalam proses CI, yang diusulkan dalam permulaan penelitian ini. Berbagi pengetahuan dan persepsi tentang lingkungan kompetitif oleh karyawan adalah dasar 
untuk memahami dan mengantisipasi ancaman dan peluang di pasar dan pendukung penting untuk pengambilan keputusan. Maka dari itu perusahaan harus dapat menerapkan CI dalam proses berbagi pengetahuan dan informasi mengenai pesaing dan lingkungan bisnis untuk dapat merespon lingkungan bisnis yang sangat dinamis.

Dengan menerapkan CI dalam perencanaan ekpansinya, Grab mampu memimpin pangsa pasar Ride-Hailling di seluruh mayoritas negara di asia tenggara. Penelitian yang dilakukan oleh (Dewi; Darma, 2019) mengenai The Role of Marketing \& Competitive Intelligence In Industrial Revolution 4. Yang dilakukan oleh grab menemukan bahwa Grab memilih negara ekspansi dengan melihat kemiripan yang ada di negara sebelumnya dengan proses CI, sehingga proses duplikasi bisa berjalan dengan mudah, misalnya Grab Bike di Vietnam adalah hasil duplikasi dari operasional Grab di pasar Indonesia. Grab memahami cara untuk dapat diterima di suatu negara, mereka harus memahami kebutuhan negaranya, karena kebutuhan di setiap negara berbeda beda. Untuk dapat bersaing dengan produk lokal yang sudah ada maka dilakukan pendekatan Hyperlocal dan local partnership yang sedari awal grab ketahui melalui proses CI terhadap pemimpin pasar di sektor yang sama dengan mereka.

Proses marketing bergerak secara dinamis dari masa ke masa. Pada saat ini pendekatan marketing yang relevan di lakukan saat ini adalah dengan Marketing 4.0. Penelitian yang ditemukan oleh (Lugra Agusta Pranawa \& Abiyasa, 2019) dengan memanfaatkan strategi digital seperti $E$-commerce, blog, dan media sosial perusahaan dapat mengoptimalkan pemasaran secara digital. Hedonism yang dikombinasikan dengan cara Marketing 4.0 yaitu digital marketing menyuguhkan gambaran visual yang dapat meningkatkan daya tarik konsumen. Strategi digital marketing dan hedonism ini dapat meningkatkan keputusan pembelian melalui faktor psikologi dan faktor sosial khususnya pada bagian kelompok referensi sehingga diharapkan strategi ini dapat memberikan hasil penjualan yang maksimal kepada perusahaan.

Pertumbuhan startup yang menyebabkan perubahan di landscape bisnis dunia dan terutama di Indonesia sedang mengalami ujian, salah satu nya adalah startup Besthostels Indonesia. Sektor pariwisata yang sedang tumbuh dan juga pemanfaatan teknologi yang sedemikian luas diperlambat secara mendadak dengan datang nya krisis pandemi pada saat ini. Maka dari itu kemampuan Besthostels Indonesia untuk bertahan saat krisis ini menjadi kebutuhan untuk dipelajari secara praktis dan juga akademik sehingga bisa di masa yang akan datang dapat implementasikan di dunia bisnis secara nyata. Strategi Besthostels dalam mencari pasar ceruk yang baru di antara persaingan yang begitu ketat di era VUCA ini akan memberikan gambaran bagaimana strategi yang tepat untuk bertahan di era setelah dikala pandemi ini dan juga setelah pandemi ini berakhir yang dilakukan oleh Besthostels Indonesia. Sehingga penelitian ini memiliki perbedaan dengan penelitian teradahulu karena dilakukan di saat terjadi nya krisis pandemi dengan tempat penelitian nya sangat terdampak krisis pandemi dikarenakan sangat bergantung nya ekonomi daerah terhadap sektor pariwisata. Manfaat dari penelitian ini adalah memberikan paparan strategi terknini yang efektif dan dapat digunakan oleh sektor bisnis secara luas untuk dapat bertahan ketika krisis sedang terjadi. Selain itu pemanfaatan competitive intelligence dan marketing 4.0 yang di paparkan dalam penelitian ini 
dapat digunakan lebih baik dan efektif oleh kebanyakan perusahaan agar dapat terus profitable dan juga dapat bertahan ketika terjadi krisis.

\section{Metode Penelitian}

Metode kualitatif deskriptif digunakan dalam penelitian ini. Subjek dari peneletian ini adalah Besthostels Indonesia yang berada di Jakarta, Bali dan Lombok. Untuk menjawab pertanyaan dari penelitian ini, wawancara semi-terstruktur dan mendalam dilakukan terhadap 6 narasumber dengan latar belakang berbeda dengan pertanyaan yang berbeda. Chief Executive Officer dan Chief Marketing Officer dari besthostels Indonesia adalah dua narasumber utama dalam penelitian ini untuk menanyakan mengenai strategi apa yang mereka gunakan agar besthostels indonesia dapat bertahan di krisis pandemi yang terjadi. Selain itu terdapat pula 2 pemilik hostel yang mendaftarkan property mereka pada platform besthostels Indonesia, serta 2 konsumen yang sudah pernah melakukan booking hostel selama lebih dari dua kali pada platform besthostels Indonesia.

Daftar pertanyaan wawancara dibangun berdasarkan penelitian Competitive Intelligence terdahulu yang dilakukan oleh (Ali Köseoglu et al., 2016), (de Almeida et al., 2016) dan juga penelitian mengenai marketing 4.0 yang dilakukan oleh (Dewi; Darma, 2019). Pertanyaan dalam penelitian ini juga ikut berkembang menyesuaikan topik yang sedang di bahas selama wawancara berlangsung. Maka dari itu muncul beberapa pertanyaan dan tema baru dikarenakan banyak insight yang ditemukan baru pada saat proses wawancara dan analisis data. Wawancara dilakukan selama 4 bulan dimulai dari bulan september sampai dengan bulan desember 2020 di kota jakarta, denpasar, canggu dan ubud.

Secara garis besar terdapat masing masing 6 pertanyaan untuk narasumber berbeda, yang terbagi dalam 3 bagian narasumber yaitu partisipan manajemen, partisipan pemilik property dan partisipan konsumen masing-masing (Sugiyono, 2017) dalam penelitian masing masing pertanyaan yang diajukan kepada pihak pemilik property hostel dan pihak konsumen untuk mengeksplorasi lebih jauh mengenai keuntungan menggunakan platform besthostels indonesia serta apakah strategi yang dijalankan oleh besthostels indonesia saat ini sesuai untuk menjawab situasi krisis yang sedang terjadi.

Wawancara dilakukan dengan durasi rata-rata 40 menit, dan pada beberapa narsumber dilakukan selama 2 kali dalam hari yang berbeda untuk penggalian informasi yang lebih mendalam. Wawancara direkam dengan perekam audio komputer atas ijin dari partisipan. Data dari audio tersebut kemudian diubah menjadi transkrip wawancara. Transkrip wawancara di baca dan direduksi dengan hati-hati untuk menentukan kode- kode yang dapat mewakili sekumpulan ide/pemikiran serupa. Kode-kode tersebut kemudian di kelompokkan menjadi satu tema besar. Beberapa tema tersebut dan kemungkinan hubungan antar tema diidentifikasi untuk dapat merumuskan suatu model yang dapat menggambarkan fenomena yang diteliti. Keseluruhan proses ini disebut dengan proses coding dan themeing yang dilakukan dengan bantuan spreadsheet Microsoft Excel (Miles et al., 2018).

Kutipan-kutipan penting yang mewakili kode tertentu di dokumentasikan dalam kolom kode yang sesuai, untuk dapat dipergunakan dalam pembahasan hasil. Agar penyusunan laporan menjadi lebih efisien, masing partisipan diberi kode. Chief Executive 
Officer besthostels Indonesia M1 dan Chief Marketing Officers besthostels Indonesia M2, P1 dan P2 untuk dua partisipan pemilik property hostel, K1 dan K2 untuk partisipan konsumen besthostels indonesia. Setiap kutipan yang dipaparkan dalam pemaparan hasil diakhiri dengan kode partisipan yang menyatakan pernyataan tertentu.

\section{Hasil dan Pembahasan}

\section{A. Hasil}

Analisis wawancara menunjukan bahwa competitive intelligence, marketing 4.0 dan citizen 4.0 merupakan faktor utama yang digunakan untuk perumusan strategi besthostels Indonesia untuk bertahan di saat krisis pandemi. Walaupun dalam penelusuran lebih lanjut di temukan faktor/tema baru yaitu investor funding sebagai hal krusial yang membantu mereka untuk bertahan. Berikut adalah penjelasan lebih detail untuk masing masing faktor tersebut.

\section{Competitive Intelligence}

Secara umum terdapat empat kode utama yang diidentifikasi terkait faktor competitive intelligence terhadap strategi untuk bertahan di saat krisis pandemi, yaitu: 1. Melakukan pencarian informasi mengenai pesaing; 2. Menggunakan berbagai media untuk mendapatkan informasi; 3. Informasi dari berbagai industri; 4. Menggunakan informasi untuk perumusan strategi perusahaan;

a) Melakukan pencarian informasi mengenai pesaing

Besthostels Indonesia memiliki sub-divisi sendiri untuk penggalian informasi mengenai pesaing dan juga industri bisnis secara luas. Mereka yang ada pada sub divisi ini memang memiliki job-desc untuk memberikan laporan mingguan mengenai aktivitas yang dilakukan oleh pesaing utama mereka, yang sedang terjadi di pasar dan juga bagaimana kebijakan dari pemerintah. Selain ada 1 kelompok yang melakukan job-desc tersebut, team dari marketing juga biasanya ikut membantu dalam pemberian data mengenai pasar dan pesaing utama. Kebanyakan dari informasi yang dikumpulkan adalah data mengenai aktivitas pesaing dan juga aktivtias yang dilakukan platform digital lain di sektor yang berbeda. Sebagaimana dinyatakan M1 "'berbagai informasi tentang platform digital sangat penting bagi kita" (M1). Selain melihat aktivitas dari platform digital, besthostels indonesia juga sering melihat apa yang sedang tren di sektor industri pariwisata maupun sektor industri lain nya. Manajemen melihat apabila strategi dan konten mereka sesuai dengan tren yang ada saat ini, akan membuat strategi mereka lebih efektif. Seperti dinyatakan oleh M2 "" biasanya ngeliat sih apa tren yang lagi trending di industri saat ini," (M2). Dalam penentuan harga akomodasi hostel nya besthostels Indonesia juga sering melakukan perbandingan dengan platform booking hostel internasional yaitu hostelworld. Walaupun cakupan pasar besthostels Indonesia tidak sebesar hostelworld yang ada diseluruh dunia, tapi penentuan harga dan langkah promosi yang dilakukan hostelworld masuk dalam pertimbangan perumusan strategi besthostels Indonesia. Seperti 
dinyatakan M1: "kita kalo mau listing harga pasti lihat dulu deh berapa harga yang dirilis sama hostel world untuk akomodasi tersebut" (M1).

\section{b) Menggunakan berbagai media untuk mendapatkan informasi}

Banyak media yang digunakan oleh manajemen besthostels Indonesia untuk mendapatkan informasi mengenai pesaing utama dan tren yang sedang terjadi. Salah satu yang digunakan adalah penggunaan media digital seperti media sosial, website, dan juga aplikasi dari platform pesaing nya. Penggunaan media online seperti media sosial menurut mereka adalah cara yang paling sering dilakukan karena informasi didapatkan bisa secara real time dan juga penggunaan nya mudah karena melalui smartphone. Tapi cara efektif lain nya adalah penggunaan website seperti similarweb yang menyajikan data yang lengkap dimulai dari aktivitas yang dilakukan pengguna, segmentasi konsumen, hingga konten apa saja yang paling banyak di klik di website dan juga di aplikasi platform pesaing. Seperti dinyatakan M1: “ "biasanya kita melihat informasi mengenai mereka via website yang nama nya similarweb.com dan juga feed media sosial mereka"(M1).

Selain penggunaan media digital untuk mendapatkan informasi mengenai pesaing dan juga industri, besthostels Indonesia juga sering melakukan pengumpulan informasi secara langsung. Acara seribu startup yang di inisiasi oleh pemerintah setiap tahun nya adalah ajang yang dinantikan oleh besthostels indonesia untuk mengumpulkan informasi secara langsung dari startup lain nya. Selain acara seribu startup dari pemerintah, sering kali platform besar seperti traveloka dan gojek mengadakan kegiatan sharing season dengan startup yang baru berdiri, di kesempatan inilah besthostels Indonesia mengumpulkan informasi melalui ngobrol dengan karyawan platform lain. Seperti dinyatakan M2: "tapi yang lebih efektif biasanya team kita dari marketing ikut datang ke setiap acara yang dilakukan oleh OTA dan platform digital sih untuk ngobrol dan sharing perihal informasi yang kita dan mereka punya" (M2).

c) Informasi dari berbagai industri

Penggunaan informasi sangatlah penting bagi ke berhasilan strategi perusahaan. Informasi mengenai pesaing dan juga sektor industri yang besthostels Indonesia tempati memberikan gambaran penting bagaimana posisi perusahaan. Akan tetapi mengumpulkan informasi hanya dari pesaing dan sektor bisnis yang ditempati belum cukup, karena persaingan bukan hanya datang dari perusahaan yang memiliki produk/jasa sejenis tapi juga dari perusahaan di sektor industri yang berbeda. Di era digitalisasi seperti sekarang, kemampuan untuk mendapatkan informasi secara menyeluruh adalah hal krusial bagi keberlangsungan perusahaan. Banyak tren bisnis yang terjadi belakangan ini dapat secara luas diterapkan walaupun sektor bisnisnya berbeda. Seperti dinyatakan oleh M2:" "bukan dari pariwisata aja tapi sampai fintech dan ecommerce kita gali trus informasi nya"(M2). Hal tersebut juga didukung dari pernyataan M1:“" "tapi industri digital lain seperti gojek dan tokopedia 
menyuguhkan data yang tidak kalah penting"(M1). Menggunakan informasi untuk perumusan strategi perusahaan.

Setelah berbagai informasi mengenai pesaing sektor bisnis yang ditempati dan juga tren yang sedang terjadi, berikutnya informasi tersebut digunakan dalam perumusan strategi besthostels Indonesia. Dalam hal ini informasi di analisa secara mendalam oleh tim business development dari besthostels Indonesia untuk melihat informasi dan tren apa saja yang penting bagi perusahan kedepannya. Hal tersebut di rangkum menjadi beberapa ide yang akan dijadikan pertimbangan dalam rapat perumusan strategi besthostels Indonesia. Salah satu yang sering digunakan besthostels Indonesia adalah informasi mengenai flow dari website pesaing dan juga platform digital lain nya. Seperti dinyatakan oleh M1 "kita coba modifkasi dan mengaplikasikan flownya di website dan apps yang kita punya"(M1). Selain itu informasi yang di dapatkan juga digunakan untuk menentukan seberapa besar budget yang akan digunakan untuk iklan di kanal digital seperti facebook ads dan google adsense. Seperti dinyatakan oleh M2: “ dari informasi yang di summary tersebut, kita bisa tahu seberapa besar budget yang akan kita keluarkan di digital ads"(M2).

\section{Marketing 4.0}

Saat ini perusahaan tidak bisa lagi melakukan pemasaran secara satu arah, yaitu dari perusahaan ke konsumen saja akan tapi juga harus membuat interaksi dengan konsumen. Dalam marketing 4.0 istilah ini disebut sebagai co-creation atau memberikan ruang kreasi bagi konsumen untuk menanggapi aktivitas perusahaan secara langsung. Besthostels Indonesia sebagai platform digital juga mengusung cocreation dalam pembuatan konten nya di media sosial. Salah satu contoh nya adalah pemberian give away menginap gratis di hostel terbaik bagi para followers nya di Instagram dan juga facebook dengan cara menjawab quiz yang diberikan. Seperti dinyatakan oleh M1: "di Instagram dan facebook kita buat quiz dan 20 orang yang jawab benar dapet hadiah untuk menginap di hostel secara gratis"(M1). Ternyata hal ini di konfirmasi dua narasumber yaitu P1 yang menyatakan: "bulan lalu kita menjadi salah satu yang terpilih menjadi hostel dalam giveaway nya, semua nya ditanggung oleh team mereka "(P1) dan juga K1: "aku menang giveaway nginep di Gypsymoon canggu karena benar jawab quiz nyaaa " (K1).

Banyak media yang dapat digunakan perusahaan dalam melakukan aktivitas promosi. Dahulu televisi, billboard dan juga brosur menjadi media promosi yang paling efektif karena dapat menjangkau masyarakat secara luas, di marketing 4.0 hal ini dikatakan sebagai saluran offline. Akan tetapi beberapa saat lalu muncul media sosial yang lebih sering digunakan oleh masyarakat. Masing masing media sosial seperti facebook dan google memiliki tools iklan nya sendiri, seperti facebook ads dan google adwords. Iklan di media sosial memiliki kelebihan daripada iklan di televisi karena bisa di personalisasi target konsumen nya mulai dari umur, aktivtias di media sosial, dan kegemaran. 
Dalam marketing 4.0 peran antara saluran offline dan online sangat penting untuk di padukan, istilahnya adalah omni channel marketing. Sebagai platform digital ternyata besthostels Indonesia juga melakukan omni channel marketing. Seperti dinyatakan M1:" "platform online nya kita pakai kebanyakan media sosial, untuk offline kita kasi brosur yang isi nya QR Code yang kalo di scan langsung menuju website nawarin hostel terbaik kita"(M1). Walaupun fokus utama mereka adalah channel online yaitu melalui media sosial seperti yang dinyatakan oleh P1: "kebanyakan saya lihat sih emang mereka fokus nya di dunia online" (P1). Pernyataan tersebut didukung penjelasan serupa oleh tiga partisipan lain nya (P2, K1 dan K2).

Elemen ketiga dari marketing mix yaitu palace sudah berubah menjadi aktivitas komunal dalam marketing 4.0. Saluran distrbusi pada marketing mix ini yang berperan menghantarkan produk ataupun jasa kepada konsumen. Praktik channeling di dunia yang serba horizontal berubah dari place menjadi komunal, dimana bukan hanya menyediakan touch point antara konsumen dan perusahaan tetapi juga memberikan kemudahan akses dan juga pengalaman yang berbeda terhadap konsumen, mau itu secara online ataupun offline. Besthostels Indonesia sendiri mengakui bahwa nilai lebih yang mereka tawarkan dibanding platform lain adalah mengadakan aktivitas komunal seperti acara gathering dan juga workshop untuk para pengguna hostel. Seperti dinyatakan oleh K1: " "sempat sih ikut event mereka yang BBQ an dan juga coffee season nya" (K1). Yang juga di konfirmasi oleh P1 : “"pernah waktu itu di undang sama team mereka untuk menghadiri acara talkshow di salah satu hostel" (P1).

Teknologi informasi seperti media sosial memungkinkan ruang komunikasi dua arah antara konsumen dengan konsumen ataupun konsumen ke perusahaan. Hal ini membuat konsumen mampu untuk berinteraksi, kolaborasi dan juga berpartisipasi di setiap aktivitas yang dilakukan oleh perusahaan. Besthostels Indonesia juga memanfaatkan kanal online nya seperti di Instagram dan juga facebook dengan melakukan survey mengenai keinginan konsumen, dan juga ekspriental marketing. Seperti dinyatakan oleh K1: "seringan sih liat mereka ngadain tanya jawab di ig live sama followers mereka" (K1). Selain itu penggunaan fitur review pada platform besthostels Indonesia juga memungkinkan konsumen memberikan komentar secara jujur dan juga berinteraksi langsung dengan konsumen besthostels Indonesia lain nya. Seperti dinyatakan oleh M1 :" "dengan adanya fitur review dan rating pada website, mereka bisa memberikan pengalaman nya dengan orang lain" (M1). Pernyataan tersebut didukung penjelasan serupa oleh 4 partisipan lain nya (M2,P1,P2 dan K2).

\section{Citizen 4.0}

Karena minim nya pengalaman, anak muda (youth) senang mencoba sesuatu yang baru. Lihat saja ketika produk seperti smartphone dan makanan baru pasti anak muda yang akan mencoba nya terlebih dahulu. Maka dari itu banyak perusahaan seperti apple dan google memfokuskan aktivitas promosi mereka kepada anak muda. Setelah anak muda terbiasa menggunakan hal baru tersebut dan menjadi tren, baru generasi di atas nya ikut mencoba hal baru tersebut. Besthostels Indonesia sebagai 
platform yang ingin menawarkan pengalaman berbeda ketika berwisata dengan hostel nya pun memiliki konsumen yang mayoritas adalah anak muda. Seperti dinyatakan oleh M2 : "milenials nih, mereka sangat senang dengan sesuatu yang belum pernah dirasakan oleh orang lain" (M2) yang juga didukung oleh pernyataan dari K1: "mereka yang nginep disaana rata rata anak muda backpackersan atau anak muda yang kerja nya digital" (K1).

Selain menyajikan pengalaman berwisata yang berbeda seperti aktivitas bercengkrama dengan tamu lain dan aktivitas komunal, hostel juga terkenal karena menawarkan akomodasi yang terjangkau. Dengan model bunk bed yang merupakan jenis tempat tidur di mana satu bingkai tempat tidur ditumpuk di atas yang lain. Hal ini memungkinkan dua atau lebih tempat tidur untuk menempati ruang yang biasanya hanya dibutuhkan oleh satu tempat tidur seperti hotel. Kebanyakan hostel yang ada menyediakan 6-12 tempat tidur di setiap ruangan nya, sehingga membuat harga nya terjangkau. Seperti pernyataan dari K2: "menurutku dengan harga 80 sampe 150 emang murah banget sih"(K2). Partisipan K1 lebih jauh menjelaskan bahwa harga hostel sebenarnya tidak jauh berbeda dengan hotel bintang 2, akan tetapi experience yang diberikan hotel lebih lengkap, 'bisa dikatakan affordable lah ya karena kan range harga nya mirip juga sama hotel melati, tapi emang sih hostel lebih banyak kegiatan nya" (K1).

Bukan hanya karena akomodasi nya terjangkau anak muda memilih untuk menginap di hostel. Media sosial seperti Instagram menyajikan banyak individu yang mendokumentasikan kegiatan nya di tempat yang indah di berbagai dunia, dan menunjukan bahwa pengalaman berlibur di tempat baru membuat individu terlihat menarik di mata teman dan followers nya. Bukan hanya pengalaman selama liburan yang menarik anak muda, sebagai generasi yang memiliki informasi berlimpah di internet membuat mereka senang memiliki teman dari negara yang berbeda. Seperti dinyatakan oleh K1: "seneng aja gitu kalo ketemu orang dari negara yang berbeda jadi bisa tau budaya nya " (K1).

\section{Investor Funding}

Pada saat wawancara dan juga analisis data dalam penelitian ini menemukan sebuah faktor baru yang membuat besthostels Indonesia dapat bertahan dan melakukan ekspansi di saat banyak platorm travel lain mengalami kemunduran. Faktor tersebut adalah pendanaan dari investor atau investor funding. Mendapatkan suntikan dana dari Angel Investor sebesar 30 milyar rupiah pada tahun 2020 lalu membuat besthostels Indonesia dapat terus melakukan ekspansi keseluruh daerah yang ada di Indonesia. Dana itu digunakan untuk menganalisa pasar dengan CI, membuat konten digital yang menarik, hingga merekrut puluhan karyawan profesional untuk mengembangkan platform besthostels Indonesia. Seperti dinyatakan oleh M1: "pendanaan investor itu ibarat darah, tanpa itu semua strategi yang kita buat gak akan bisa jalan" (M1).

Pendanaan dari investor tersebut di dapatkan besthsostels Indonesia karena analisis pasar yang dilakukan manajemen mendapatkan data bahwa jumlah 
backpackers dan digital nomad akan terus membesar hingga sepuluh tahun mendatang. Walaupun saat ini sedang terjadi krisis pandemi, banyak investor yang percaya bahwa tren digital nomad dan juga backpacker akan kembali tumbuh setelah vaksinasi covid 19 secara massal di lakukan di seluruh dunia. Seperti dinyatakan M2: "mereka ngeliat prospek hostel itu cerah abis pandemi ini, apalagi melihat trend work from everywhere yang terjadi belakangan ini" (M2).

\section{B. Pembahasan}

Penelitian ini mengindikasikan bahwa competitive intelligence menjadi salah satu faktor penting yang membuat besthostels Indonesia dapat bertahan di saat krisis pandemi. Dari penjelasan yang dijabarkan oleh Chief Executive Officer dan juga Chief Marketing Officer besthostels Indonesia, terdapat 4 aktivitas CI yang dilakukan di besthostels Indonesia. Sebagai platform yang menawarkan akomodasi hostel dan pariwisata, besthostels Indonesia memiliki banyak sekali pesaing dari platform pariwisata lain nya. Di besthostels Indonesia mereka memiliki sub divisi khusus yang mengumpulkan informasi mengenai pesaing, tren yang sedang terjadi dan juga kebijakan pemerintah. Dalam menentukan harga setiap hostel nya besthostels indonesia selalu membandingkan nya dengan platform hostelworld, untuk memberikan harga yang bersaing kepada konsumen. Maka dari itu aktivitas CI pertama yang mereka lakukan adalah melakukan pencarian informasi secara berkala mengenai pesaing.

Berbagai media digunakan oleh manajemen besthostels Indonesia untuk mengumpulkan informasi mengenai pesaing dan tren yang terjadi. Media yang paling sering digunakan besthostels Indonesia adalah media digital seperti media sosial, karena menyajikan data secara realtime. Selain itu penggunaan website seperti similarweb juga efektif untuk memantau pesaing dan juga platform digital lainnya. Website ini memberikan data aktivitas pengguna yang lengkap dari platform pesaing besthostels indonesia, dimulai dari aktivitas di lakukan di website, segmentasi konsumen, hingga konten apa saja yang paling banyak di klik di website tersebut.

Akan tetapi cara mengumpulkan informasi yang menurut besthostels indonesia paling efektif adalah dengan menghadiri sharing season yang di adakan oleh pemerintah seperti acara seribu startup ataupun sharing season yang di adakan platform digital lain. Mereka bisa mengumpulkan informasi secara langsung melalui obrolan dengan karyawan dan juga founder dari startup lain nya.

Temuan dalam penelitian ini mengidikasikan bahwa kemampuan perusahaan untuk mendapatkan informasi secara menyeluruh dari pesaing dan juga industri lain adalah hal krusial bagi keberlangsungan perusahaan. Kebanyakan tren yang terjadi belakangan ini dapat secara luas diterapkan di industri berbeda. Maka dari itu besthostels Indonesia melakukan pencarian informasi dari financial technology sampai dengan e-commerce, agar mereka mendapatkan informasi yang menyeluruh. Hal ini senada dengan penelitian yang dilakukan oleh (de Almeida et al., 2016) yang menjelaskan bahwa kesesuaian antara perusahaan dengan lingkungan nya menjadi prediksi utama bagi keberhasilan kinerja organisasi, dan pemindaian lingkungan secara menyeluruh adalah cara paling efektif untuk mencapai nya. 
Setelah semua informasi tersebut dikumpulkan, langkah selanjut nya analisa yang dilakukan oleh sub divisi khusus yang dimiliki besthostels Indonesia. Informasi nya di analisa secara mendalam untuk melihat informasi dan tren apa saja yang penting bagi perusahaan kedepan nya. Hal tersebut dijadikan rangkuman beberapa ide yang akan di presentasikan dan dijadikan pertimbangan dalam rapat perumusan strategi besthostels Indonesia.

Penelitian ini menguatkan dua penelitian sebelum nya yang dilakukan oleh (Ali Köseoglu et al., 2016) yang mengindikasikan bahwa dengan melakukan langkah langkah CI seperti menganalisa kompetitor, melihat lingkungan bisnis dan juga menyesuikan harga dengan pasar membuat perusahaan lebih mampu menerapkan strategi yang efektif. Dengan menerapkan strategi yang efektif menyebabkan perusahaan memiliki tingkat kinerja yang lebih baik, seperti yang dilakukan oleh besthostels Indonesia pada saat krisis pandemi.

Saat ini perusahaan dituntut untuk bisa membuat interaksi dengan konsumen, bukan lagi melakukan pemasaran secara satu arah seperti dahulu. Co-creation adalah istilah yang digunakan untuk memberikan ruang kreasi dan interaksi bagi konsumen untuk menanggapi aktivitas perusahaan. Besthostels Indonesia menggunakan pendekatan quiz dan giveaway untuk melakukan interaksi dengan para konsumen dan followers nya di media sosial. 20 orang yang beruntung menjawab quiz dengan benar mendapatkan voucher gratis menginap di hostel terbaik di seluruh indonesia yang ada di platform besthostels Indonesia. Semua biaya dari giveaway besthostels Indonesia itu di tanggung penuh oleh pihak manajemen.

Untuk melakukan aktivtias pemasaran nya besthostels Indonesia memfokuskan diri menggunakan pendekatan media sosial. Penggunaan ads di media sosial seperti facebook ads dan google adwords adalah aktivitas pemasaran utama yang dilakukan oleh besthostels Indonesia, karena mereka mengincar milenials yang memang lebih banyak menghabiskan waktu nya di media sosial. Akan tetapi cara offline seperti pembagian brosur tetap dilakukan besthostels Indonesia ketika sedang menghadiri acara sharing season ataupun gathering.

Tapi dalam brosur tersebut ada sebuah QR Code yang apabila di scan akan langsung terbuka website besthostels Indonesia beserta pilihan hostel terbaik nya. Ini dilakukan besthostels Indonesia untuk memberikan lebih banyak media yang dapat di akses oleh calon konsumen. Temuan penelitian menguatkan penelitian sebelum nya yang mengindikasikan bahwa pemanfaatan strategi digital membuat pemasaran yang dilakukan oleh perusahaan lebih optimal. Dan hal ini meningkatkan keputusan pembelian konsumen terhadap perusahaan (Lugra Agusta Pranawa \& Abiyasa, 2019).

Praktik channeling di dunia yang serba horizontal berubah dari place kearah aktivtias komunal, dimana bukan hanya menyediakan touch point antara konsumen dan perusahaan tetapi juga memberikan kemudahan akses konsumen terhadap perusahaan, mau itu secara online ataupun offline. Aktivitas komunal yang dilakukan besthostels Indonesia adalah dengan cara mengadakan acara gathering dan juga workshop untuk para pengguna hostel. Hal ini senada dengan buku marketing 4.0 (Kotler et al, , 2017) yang 
mengindikasikan bahwa aktivitas komunal menyebabkan interaksi yang lebih dalam antara perusahaan dengan konsumen.

Selanjut nya temuan penelitian ini juga mengindikasikan bahwa perkembangan teknologi informasi memungkinkan ruang komunikasi dua arah antara konsumen dengan konsumen menggunakan media sosial. Konsumen mampu untuk berinteraksi, kolaborasi dan juga ikut berpartisipasi di setiap aktivitas yang dilakukan oleh perusahaan. Besthostels Indonesia menggunakan Instagram dan facebook untuk melakukan experiental marketing. Cara yang besthostels indonesia lakukan adalah dengan mangadakan Quest and Answer dalam Instagram live setiap minggunya. Selain itu fitur review dan rating yang ada pada website besthostels Indonesia memberikan ruang bagi konsumen untuk membagikan pengalaman menginap di hostel dan juga memberikan komentar mengenai pengalaman konsumen lain nya. hal ini mendukung penelitian yang dilakukan oleh (Othman et al., 2019).

Besthostelsl Indonesia sebagai platform yang menawarkan pengalaman berbeda ketika berwisata dengan menginap di hostel memiliki konsumen yang mayoritas adalah anak muda. Minim nya pengalaman anak muda membuat mereka senang mencoba sesuatu yang baru. Anak muda ini tertarik karena hostel menyajikan pengalaman berwisata yang berbeda seperti aktivitas bercengkrama dengan tamu lain dan aktivitas komunal dengan harga yang terjangkau. Dengan model bunkbed biasanya hostel yang ada di platform besthostels Indonesia itu menyediakan 6-12 tempat tidur di setiap ruangan nya, sehingga membuat harga nya terjangkau.

Dimulai dari 80 sampai 200 ribu rupiah anak muda sudah dapat menginap, snack gratis, kolam renang dan juga aktivitas komunal dengan tamu dari negara berbeda. Walaupun menurut beberapa partisipan harga nya itu sama saja dengan hotel kelas melati, tapi kegiatan dan juga pengalaman yang diberikan hostel jauh lebih banyak. Salah satu pengalaman itu berupa berkenalan dan berkomunikasi dengan individu dari negara yang berbeda. Karena kebanyakan yang menggunakan hostel itu masih orang dari luar negeri, banyak anak muda yang tertarik datang ke hostel untuk memiliki teman baru dari negara yang berbeda.

Salah satu faktor penting yang membuat besthostels Indonesia mampu bertahan dan melakukan ekpansi di saat banyak platform travel dan digital lain mengalami kemunduran adalah faktor pendanaan atau investor funding. Dana sebesar 30miliyar rupiah di dapatkan besthostels Indonesia pada tahun 2020 lalu dari angel investor untuk melakukan ekspansi keseluruh Indonesia, menganalisa pasar dengan CI, membuat konten digital dan juga merekrut puluhan professional. Walaupun saat ini sedang terjadi krisis pandemi, investor dari besthostels Indonesia sendiri percaya bahwa tren backpackers dan digital nomad akan mengalami pertumbuhan kembali setelah vaksinasi terlaksana. Chief Executive Officer besthostels Indonesia selanjutnya menyebut bahwa pendanaan investor itu seperti darah yang membuat semua aktivitas perusahaan nya dapat terlaksana. Penelitian ini menguatkan penelitian sebelum nya yang dilakukan oleh (Garg \& Shivam, 2017) yang mengindikasikan bahwa nya peran pendanaan dari investor untuk keberlangsung usaha dan kemajuan dari sebuah startup sangatlah krusial. 


\section{Kesimpulan}

Penelitian ini menemukan bahwa strategi agar perusahaan rintisan dapat bertahan disaat terjadi krisis dipengaruhi oleh 4 faktor utama, yaitu : (1) Competitive Intelligence, yang diterapkan oleh perusahaan dengan cara melakukan pencarian informasi mengenai pesaing hingga penggunaan informasi tersebut dalam strategi perusahaan;(2) Marketing 4.0, berupa penggunaan omni channel marketing, co creation, aktivitas komunal dan experiental marketing; (3) penggunaan Citizen 4.0 untuk mendapatkan target konsumen yang relevan dengan perusahaan; (4) peran krusial dari pendanaan investor agar perusahaan dapat melakukan semua strategi yang dirancang, dan juga bertahan di saat banyak perusahaan rintisan lain nya yang mengalami penurunan di saat krisis pandemi terjadi.

Penelitian ini memiliki implikasi bagi para pebisnis maupun individu yang berniat untuk mendirikan sebuah perusahaan rintisan. Faktor faktor yang menentukan keberhasilan sebuah perusahaan rintisan perlu di pahami dengan baik, mengingat peran signifikan nya competitive intelligence, marketing 4.0, citizen 4.0 dan juga investor funding bagi keberhasilan perusahaan rintisan dalam penelitian ini.

Penelitian ini merekomendasikan penerapan strategi Competitive Intelligence yang dilakukan secara online dan juga offline dalam mengumpulkan informasi secara menyeluruh. Informasi mengenai pesaing dan juga sektor industri memberikan gambaran penting bagaimana posisi sebuah perusahaan. Akan tetapi mengumpulkan informasi hanya dari pesaing dan sektor bisnis yang ditempati tentu nya belum cukup, karena persaingan bukan hanya datang dari perusahaan yang memiliki produk/jasa sejenis tapi juga dari perusahaan di sektor industri yang berbeda. Di era digitalisasi, kemampuan untuk mendapatkan informasi secara menyeluruh adalah hal krusial bagi keberhasilan sebuah perusahaan.

Penelitian ini telah berupaya melakukan eksplorasi mendalam atas faktor faktor yang membuat sebuah perusahaan rintisan dapat bertahan di saat krisis pandemi terjadi dengan mewawancarai Chief Executive Officer dan juga Chief Marketing Officer dari besthostels Indonesia. Untuk memberikan informasi yang menyeluruh dengan triangulasi sumber, penelitian ini juga mewawancarai dua pemilik hostel yang mendaftarkan property nya di platform besthostels Indonesia serta dua konsumen yang sudah melakukan reservasi lebih dari dua kali di platform besthostels Indonesia.

Akan tetapi, karena penelitian ini hanya berfokus pada strategi yeng dilakukan oleh besthostels Indonesia, temuan penelitian ini mungkin saja kurang relevan untuk konteks perusahahaan yang lebih besar. Dengan demikian, untuk menyempurnakan temuan penelitian ini, penelitian berikutnya dapat dilakukan pada konteks perusahaan yang berbeda di daerah yang memiliki karakteristik berbeda dari Bali. Agar dapat di generalisasi, penelitian berikutnya dapat melakukan pengujian model melalui metode kuantitatif dengan penyebaran kuesioner yang melibatkan responed yang luas. 


\section{BIBLIOGRAFI}

Agung, N. F. A., \& Darma, G. S. (2019). Opportunities and Challenges of Instagram Algorithm in Improving Competitive Advantage. International Journal of Innovative Science and Research Technology, 4(1), 743-747. Google Scholar

Ali Köseoglu, M., Ross, G., \& Okumus, F. (2016). Competitive intelligence practices in hotels. International Journal of Hospitality Management, 53, 161-172. https://doi.org/10.1016/j.ijhm.2015.11.002 Google Scholar

Andriani, S.Si, Apt, M.Sc, Ph.D, H. (2020). Effectiveness of Large-Scale Social Restrictions (PSBB) toward the New Normal Era during COVID-19 Outbreak: a Mini Policy Review. Journal of Indonesian Health Policy and Administration, 5(2), 61-65. https://doi.org/10.7454/ihpa.v5i2.4001 Google Scholar

De Almeida, F. C., Lesca, H., \& Canton, A. W. P. (2016a). Intrinsic motivation for knowledge sharing-competitive intelligence process in a telecom company. Journal of Knowledge Management. Google Scholar

De Almeida, F. C., Lesca, H., \& Canton, A. W. P. (2016b). Intrinsic motivation for knowledge sharing - competitive intelligence process in a telecom company. Journal of Knowledge Management, 20(6), 1282-1301. https://doi.org/10.1108/JKM-02-2016-0083 Google Scholar

Dewi; Darma. (2019). The Role of Marketing \& Competitive Intelligence In Industrial Revolution 4.0. Manajemen Dan Bisnis, 16(1), 1-12. http://journal.undiknas.ac.id/index.php/magister manajemen/http://journal.undiknas .ac.id/index.php/magister-manajemen/ Google Scholar

Garg, A., \& Shivam, A. K. (2017). Funding to growing start-ups. Research Journal of Social Sciences, 10(2), 22-31. Google Scholar

Geng, R., Wang, S., Chen, X., Song, D., \& Yu, J. (2020). Content marketing in ecommerce platforms in the internet celebrity economy. Industrial Management and Data Systems, 120(3), 464-485. https://doi.org/10.1108/IMDS-05-2019-0270 Google Scholar

Godovykh, M., \& Tasci, A. D. A. (2020). Customer experience in tourism: A review of definitions, components, and measurements. Tourism Management Perspectives, 35(May 2019), 100694. https://doi.org/10.1016/j.tmp.2020.100694 Google Scholar

Kim, R. Y. (2020). The Impact of COVID-19 on Consumers: Preparing for Digital Sales. IEEE Engineering Management Review, 48(3), 212-218. https://doi.org/10.1109/EMR.2020.2990115 Google Scholar

Lugra Agusta Pranawa, I. P., \& Abiyasa, A. P. (2019). Digital Marketing dan Hedonisme Dalam Pengambilan Keputusan Pembelian. Jurnal Manajemen Bisnis, 16(4), 58. https://doi.org/10.38043/jmb.v16i4.2250 Google Scholar

Maritz, R., \& du Toit, A. (2018). The practice turn within strategy: Competitive intelligence as integrating practice. South African Journal of Economic and Management Sciences, 21(1), 1-14. https://doi.org/10.4102/sajems.v21i1.2059 Google Scholar

Miles, M. B., Huberman, A. M., \& Saldaña, J. (2018). Qualitative data analysis: A 
methods sourcebook. Sage publications. Google Scholar

Othman, B. A., Harun, A., Rashid, W. N., Nazeer, S., Kassim, A. W. M., \& Kadhim, K. G. (2019). The influences of service marketing mix on customer loyalty towards umrah travel agents: Evidence from Malaysia. Management Science Letters, 9(6), 865-876. https://doi.org/10.5267/j.msl.2019.3.002 Google Scholar

Seyyedamiri, N., \& Tajrobehkar, L. (2019). Social content marketing, social media and product development process effectiveness in high-tech companies. International Journal of Emerging Markets. https://doi.org/10.1108/IJOEM-06-2018-0323 Google Scholar

Sugiyono. (2017). Metode Penelitian Administrasi, Bandung: Alpabeta (Vol. 10). Pusat Pendidikan Dan Studi Kebanksentralan (PPSK) Bank Indonesia.

Swari, D. A. K. B. A., \& Darma, G. S. (2019). Kepercayaan Lintas Generasi Dalam Penggunaan Social Media dan Electronic Word of Mouth. Jurnal Manajemen Bisnis, 16(4), 145-161. Google Scholar

Turgut, Z., Aydin, G. Z. G., \& Sertbas, A. (2016). Indoor localization techniques for smart building environment. Procedia Computer Science, 83, 1176-1181. Google Scholar

\section{Copyright holder:}

Komang Gita Krishna Murti dan Gede Sri Darma (2021)

First publication right:

Journal Syntax Literate

This article is licensed under: 